\title{
The Role of Market Orientation, Creativity and Innovation in Creating Competitive Advantages and Creative Industry Performance
}

\author{
Sutapa ${ }^{\bowtie}$, Mulyana, Wasitowati \\ Faculty of Economics, Islam Sultan Agung University, Semarang, Indonesia
}

Info Article

History Article:

Received July 2017

Approved August 2017

Published September 2017

\section{Keywords:}

Market Orientation; Creativity;

Innovation; Competitive

Advantage; Performance.

\begin{abstract}
The purpose of this study is to examine the effect of market orientation, creativity, innovation and competitive advantage on the performance of creative industries. Respondents from this study are 130 owners or leaders of creative industries in the fashion sector in Central Java Indonesia. The study is located on the North Coast of Central Java, taking five districts, namely Pekalongan, Semarang, Kudus, Rembang and Jepara. Sampling method in this research use purposive sampling method. This method is used taking into account the criteria of the creative fashion industry that has been operating for at least 3 years and innovating market-oriented products. The data obtained will be analyzed using Partial Least Square (PLS) program. The results of data analysis show that creativity has no significant effect on innovation. Market orientation significantly affects innovation and performance. Innovation also has a significant effect on excellence and competitive performance. Furthermore, competitive advantage has a significant effect on company performance.
\end{abstract}

Peran Orientasi Pasar, Kreativitas dan Inovasi dalam Menciptakan Keunggulan Kompetitif dan Kinerja Industri Kreatif

\begin{abstract}
Abstrak
Tujuan dari penelitian ini adalah untuk menguji pengaruh orientasi pasar, kreativitas, inovasi dan keunggulan kompetitif terhadap kinerja industri kreatif. Responden dari penelitian ini adalah 130 pemilik atau pimpinan industri kreatif di sektor fashion di Jawa Tengah Indonesia. Penelitian berlokasi di Pantai Utara Jawa Tengah, dengan mengambil lima kabupaten, yaitu Pekalongan, Semarang, Kudus, Rembang dan Jepara. Metode pengambilan sampel pada penelitian ini menggunakan metode purposive sampling. Metode ini digunakan dengan mempertimbangkan kriteria industri fashion kreatif yang telah beroperasi minimal 3 tahun dan berinovasi produk berorientasi pasar. Data yang diperoleh akan dianalisis dengan menggunakan program Partial Least Square (PLS). Hasil analisis data menunjukkan bahwa kreativitas tidak berpengaruh signifikan terhadap inovasi. Orientasi pasar secara signifikan mempengaruhi inovasi dan kinerja. Inovasi juga berpengaruh signifikan terhadap keunggulan dan kinerja kompetitif. Selanjutnya, keunggulan kompetitif berpengaruh signifikan terhadap kinerja perusahaan.
\end{abstract}

JEL Classification: M3, M31

How to Cite: Sutapa., Mulyana \& Wasitowati. 2017. The Role of Market Orientation, Creativity and Innovation in Creating Competitive Advantages and Creative Industry Performance. Jurnal Dinamika Manajemen. 8 (2): 152-166. 
Sutapa, et al. / The Role of Market Orientation, Creativity and Innovation in...

\section{INTRODUCTION}

Creative industry is one of the backbones for economic development, it will have a greater contribution for Indonesia if it is developed well. The creative industry has a significant contribution to economic development, especially in providing jobs and increasing people's incomes. Nowadays, competitions are getting tighter, so creativity and innovation is needed to adapt on the environmental changes. Development of continuous innovation requires adequate resources, in the field of human resources, finance and technology. Small and medium enterprises' resources have an effect on organizational capability (Jardon \& Martos, 2013).

The development of market-oriented, creativity and innovation is one of the main components that encourage the creation of competitive advantage. The creation of sustainable competitive advantage for the creative industries is necessary to compete in the global market. Creativity and innovation are needed by creative industries to grow and develop. Industry actors should be able to change the outlook from profit orientation to the long term customer-oriented. To achieve business goals, creative industry players should have capability to face challenges, formulate strategies in competition (Halim et al., 2011). Rapid changes in the environment especially technology and consumer force the creative industry to adjust by adopting knowledge, skills and technology.

The ability to increase creativity in discovering new and unique ideas is needed to compete in the global market. Competitive advantage shows that companies act better than competitors in the same. Creativity in the form of product innovation should be done sustainably based on consumer's needs. The success of the creative industry to develop market-oriented, creativity and innovation products are expected to create competitive advantage.

Innovation can be a critical success factor in achieving the sustainable competitive advantage. The changing business environment drives the tight competition between companies in the global market place. It motivates the companies to have innovation strategy in winning the global market competition. For creative industries, consumer-oriented innovation is a solution to survive and ready to face the global business challenges. Management awareness to innovate drives sustainable corporate growth. Consumeroriented business decisions will drive innovation (Martinez et al., 2013; Farida, 2016).

Market orientation requires sufficient resources to create sustainable competitive advantage. Market orientation involves customers and competitors, so that creative industry players should understand the role of organizational culture. The marketing organization should understand consumer needs and deliver better value than competitors. Market orientation can improve innovation and business performance (Suliyanto \& Rahab, 2012) the success of the creative industry to develop creativity and realize in the form of new market-oriented, product innovation is expected to create competitive advantage.

Previous research studies have been conducted in different results. Some research studies show that market orientation can improve market performance (Vytlacil, 2010; Oudan, 2012). Market orientation can improve company performance (Yuan Li et al., 2008; Suliyanto \& Rahab, 2012; Yadav \& Tripathi, 2014). Other studies show that market orientation as a key determinant of Islamic banking business performance (Widana et al., 2015). Another study shows that implementation of market orientation in small and medium enterprises can improve the performance of international marketing (Armanio et al., 2008). The results also show that there is a strong relationship between consumer orientation and marketing competence in small and medium enterprises (Asikhia, 2010).

The market orientation mediates the relationship between innovation and the performance of insurance companies (Remli et al., 2013). In small and medium business of food, consumer orientation and competitor orientation have a significant effect on business per- 
formance (Aziz \& Yassin, 2010). The results of research indicate that market orientation and government regulation have a significant effect on competitive advantage (Afsharghasemi et al., 2013). Market orientation as the main determinant of Islamic banking business performance (Widana et al., 2015).

Other studies show different results, that market orientation does not significantly affect the performance of small and medium enterprises (Rosli \& Sidek, 2013; Gholami \& Birjandi, 2016). Other study shows that market orientation cannot improve the financial performance and growth of company owned by family (Gerni, 2013). Previous studies have dealt with relationships between market orientation, innovation, competitive advantage and firm performance. According to researchers still, not many who examine about creativity, especially the relationship between creativity with innovation in support of competitive advantage and performance.

Creativity is needed for creative industries in order to create competitive advantage. Therefore, the relationship between creativity and innovation is still interesting to be studied. Previous research studies have focused on small and medium scale businesses as well as insurance while the research object is creative industry. Research on creative industry has not been done by many other researchers yet, therefore it is needed. The purpose of this research is to examine the effect of market orientation and creativity on innovation, competitive advantage and performance. The results are expected to be inputs to create competitive advantage and creative industry performance.

\section{Hypothesis Development \\ Creativity and Innovation}

Organizational innovation describes cooperation in business that connects people, ideas and resources that interact and generates creativity and innovation (Sousa, 2012). Since innovation capability is a must, entrepreneur should have some skills: self-knowledge, imagination, practical knowledge, searching. Creativi- ty defines as thinking something new, while innovation is the ability to apply creativity to solve problems and opportunities. Creative thinking is the ability to find ideas, opportunities and get innovative ways to solve the problems. The main foundation to be innovative is creativity. The knowledge, skills and experience of employees in value creation will determine the success of innovation (Sugianto \& Hartono, 2017). Individual creativity is not enough to create successful innovation, as well as creativity is a prerequisite to generate innovation (Steiner, 2009).

As well as creativity is a prerequisite for the generation of innovation (Mehrabani, 2012) and creativity cannot improve innovation performance (Sohn \& Jung, 2010). Creativity is the ability to discover new ideas and new methods to meet challenges and opportunities whereas innovation is the ability to find ways to solve problems

$\mathrm{H1}$ : Creativity significantly affects innovation

\section{Market Orientation and Innovation}

Cooperation in organizations that combine people, ideas and good resources generates creativity and innovation. High market-oriented business activities encourages companies to innovate products, processes and markets (Martinez et al., 2013). Market orientation can improve innovation in both company and service industry ( Altuntaş et al., 2013). The market orientation of small and medium-sized businesses can encourage innovation (Suliyanto \& Rahab, 2012; Remli et al., 2013) and the high competitor orientation encourage the high the innovation activity (Martinez et al., 2013). Inter-functional coordination in market-oriented marketing activities can enhance innovation capabilities (Azadehdel et al., 2013).

Similarly, market orientation that emphasizes the importance of inter-functional coordination can encourage product innovation (Hosseini, 2012). Market orientation, innovation and performance have strong correlations and market orientations have a role as mediator between innovation and performance (Remli et al., 2013). Consumer orientation encourages 
Sutapa, et al. / The Role of Market Orientation, Creativity and Innovation in...

innovation and higher level of competence hence higher level of innovation (Martinez et al., 2013) and market orientation pushes innovation performance success (Kaya \& Patton, 2011). Market orientation components that include consumer orientation and competitor orientation drive new product innovation (Augusto \& Coelho, 2009). Market orientation is a key to have product and process innovation (Kok \& Biemans, 2009).

$\mathrm{H} 2$ : Market orientation significantly affects innovation

\section{Market Orientation and Performance}

Marketing activities that emphasize on consumer orientation, competitor orientation and inter-functional coordination within organizations illustrate the construction of market-oriented marketing activities. The result of previous studies indicates that business performance can be improved through market orientation (Yuan Li, 2008; Yadav; 2012; Ou \& 2012; Altuntaş et al., 2013; Hassan, 2013; Widana, 2015; Pantouvakis et al., 2017).

Furthermore, in large companies, the relationship between operational coordination and performance (business \& operational) is moderated by consumer orientation (Liu et al., 2011). Market-oriented marketing strategy does not significantly affect financial performance (Upadhyay \& Sivakumar, 2015). Business performance can be enhanced through inter-functional coordination in marketing activities (Aziz $\&$ Yassin, 2010). The performance of international marketing in small companies can be improved through market orientation (Armanio et al., 2008). Marketing performance can be improved through market orientation (Vytlacil 2010; Peter \& Danskin, 2010; Oudan, 2012). Exportoriented marketing activities improve export performance (Singh \& Mahmood, 2013).

The competitive advantage mediates the relationship between market orientation and internationalization (Afsharghasemi et al., 2013). At the product life cycle stage, the relationship between market orientation and firm performance becomes strongest when the company is at a weak and growth phase in the introductory phase (Wong \& Ellis, 2007).

Market orientation through the dimensions of consumer orientation, competitor orientation and interfunctional coordination can be used to predict company performance (Yadav \& Tripathi, 2014). Market-oriented marketing activities, competitive advantage and government regulation can drive internationalization and market orientation with international market performance also has a strong correlation (Afsharghasemi et al., 2013). Good marketing ability drives the creation of marketing performance (Santos-vijande, 2012) and relationships between innovation and company performance are mediated by market orientation (Remli et al., 2013). The business performance of small and medium businesses can be improved through consumer orientation and competitor orientation (Aziz \& Yassin, 2010). H3: Market orientation significantly affect company performance

\section{Innovation and Performance}

Innovation and experience of small and medium-sized enterprises encourage the sustainable growth (Mirza, 2011). Management ability to innovate is influenced by product quality and marketing synergy (Maatoofi \& Tajeddini, 2011). Company performance can be improved by the innovation quality (Lakhal, 2009; Salim \& Sulaiman, 2011; Mahmood, 2013; Azadehdel et al., 2013). The better and more attractive product innovation designs encourage sales growth (Dirisu et al., 2013). Similarly, the performance of small and medium enterprises can be improved through the capabilities of innovation ( $\mathrm{Su}-$ liyanto \& Rahab, 2012; Sulistyo, 2016).

A strong market orientation by the company improves innovation and impacts on improving company performance (Remli et al., 2013). Company performance can be improved through product innovation (Charterina \& Landeta, 2013) and there is a strong correlation between innovation quality and trade and industry performance (Azadehdel et al., 2013). Furthermore, innovation-oriented companies are 
able to improve company performance (Gerni, 2013), the quality of innovation also significantly affects performance (Azadehdel et al., 2013). Product innovation improves business performance (Charterina \& Landeta, 2013). Proactive environmental innovation capability significantly affects company performance (Fong \& Chang, 2012).

Strong green product innovation will have a strong impact on competitive advantage over company performance. The good environment attention having by the management encourages the strong relationship between green product innovation and company performance (Ar, 2012). Innovation, company size, demography, location and experience are positively related to the continued growth of a small and mediumsized enterprise (Mirza, 2011). Company performance is influenced by product innovation (Mahmood, 2013). High innovation creativity can improve organizational performance (Sa$\lim \&$ Sulaiman, 2011).Product innovation and process innovation in small and medium enterprises significantly affect company performance (Rosli \& Sidek, 2013).

H4: Innovation significantly affects company performance

\section{Innovation and Competitive Advantage}

The company resources and skills affect the creation of competitive advantage. The key to long-term business performance is largely determined by the company's competitive advantage. Companies' ability to deliver customer value better than competitors can create competitive advantage. The ability to create low cost operations and differentiate create sustainable competitive advantage. Competitive advantage shows that companies can act better than competitors in the same industry. Innovation and cooperation with main partner is a solution to help the cosmetic and herbal health industry to adapt with global business challenges (Permatasari \& Dhewanto, 2013). The green process innovation performance can create competitive advantage for the company (Chen \& Chang, 2013) and innovation is able to encourage the creation of competitive advantage (Wingwon, 2012). Competitive advantage can be created through superior value, quality, innovation and effectiveness (Chiou, 2011), as well as competitive advantage can be achieved through innovation motivation (Dustin et al., 2014).

The company's competitiveness is determined by intellectual capital and innovation (Sanchez-gutierrez et al., 2012).Company innovation affects the individuals and organizations performance that the impact on the creation of competitive advantage. Innovation improves sustainable competitiveness for small and medium enterprises (Najib, 2014; Widyastuti 2014) and competitive advantage is achieved through innovation motivation (Dustin et al., 2014). Sustainable market innovation is seen as a good tool in gaining sustainable competitive advantage (Ren et al., 2010). The ability to innovate has an effect on competitive advantage (Parkman et al., 2012).

H5: Innovation significantly affects competitive advantage

\section{Competitive Advantages and Performance}

Small company's ability to understand consumer needs create a good distribution network and manage sales of goods abroad effectively and efficiently improve export performance. Properly competed strategies drive business performance (Halim et al., 2011), as well as management capability affects company performance (Hsu, 2012).The high competitive advantage strengthens market orientation and impacts on the internationalization of SMEs (Afsharghasemi et al., 2013).

Business performance is significantly influenced by the competitive advantages of a company (Russell \& Millar, 2014; Mulyana, 2016) and competitive advantage significantly affects financial performance (Kamukama et al., 2011). Strong competitive advantage improves organizational performance (Lakhal, 2009; Russell \& Millar, 2014; Putri \& Yuniawan, 2016). High corporate performance is an indicator of competitive strength (Awuah, 2008). Holistic competitive advantage improves com- 
Sutapa, et al. / The Role of Market Orientation, Creativity and Innovation in...

pany performance (Ren, 2010). Market orientation, competitive advantage and government regulation significantly affect internationalization of SMEs (Afsharghasemi et al., 2013).

H6: Competitive advantage significantly affects company performance

\section{METHOD}

In this study, obtained data from the respondents used to explain the relationship between research variables. Data is analyzed by quantitative approach. The respondents of this study are the owners or the heads of creative industry in the fashion sector in Central Java Indonesia. Research is located in North Coast of Central Java, by taking five districts/ cities, namely Pekalongan, Semarang, Kudus, Rembang and Jepara.

The objectives of this study are to examine and analyze the relationship between market orientation, creativity, innovation, competitive advantage and creative industry performance. The operational definition of those research variables can be explained as follows. Market orientation is an organizational culture that has confidence and values that put customers in the center of business decisions and measured through 9 indicators adopted from the previous research (Asikhia, 2010; Vytlacil, 2010; Awwad et al., 2011; Shoemaker \& Pelham, 2013), those are: value added for consumers, understanding consumer needs, customer satisfaction, information sharing competitors, competitor action responses, competitor strategy responses, inter functional coordination, information sharing between parts, cooperation formulate strategies.

Creativity is ability of exploring new ideas and obtaining new methods of problem solving, measured by indicators adopted from the previous research (Sohn \& Jung 2010), those are: originality, uniqueness, variation, breadth of ideas. The innovation is an ability to apply creativity in solving problems and improving innovation performance which is measured by
4 indicators adopted from the previous research (Rusli, 2013), those are: introductions of new products, products with new technology, product differentiation, entering the market with new products.

Competitive advantage is the ability to act better than competitors in the same industry and it is measured by four indicators adopted from the previous research (Wingwon, 2012; Hosseini, 2012; Hsu, 2012), those are: cost, quality innovation, customer relationship and difference. Business performance is the ability to dominate the market and focus on its goal and financial, measured by 4 indicators adopted from the previous research (Asikhia, 2010; Wingwon, 2012; Karacaoglu, et al., 2013), those are: return on assets, growth profit, sales growth, market share growth.

Purposive sampling was used as the sampling technique. This method was used by considering the criteria of the creative fashion industry that has been operating for at least 3 years and innovate market-oriented products. The respondents selected in this research are the leaders of the creative industries. The data were collected by sending questionnaires, telephone interviews and field observations.

There were 180 questionnaires spread out and 150 of them were returned. Furthermore, from 150 returned questionnaires conducted to obtain accurate data. To ensure the data accuracy, it was selected 130 questionnaires which are eligible as respondents. The collected data will be tested for its validity and reliability. The measurement of the questionnaire items in this study is by use of "five-point Likert scale from 1 to 5 " rating from strongly disagreement to the strongly agreement. the obtained data will be analyzed using Partial Least Square (PLS) program. The result of data analysis is expected to explain the relationship between research variables.

\section{Respondents Description}

The description of the respondents as a whole can be explained in Table 1 . 
Table 1. Respondents Description

\begin{tabular}{lrc}
\hline \multicolumn{1}{c}{ Variable } & Amount & Percentage \\
\hline Age (in year) & & \\
20-29 & 12 & 12.00 \\
$30-39$ & 46 & 35.38 \\
$40-49$ & 55 & 42.30 \\
$50-59$ & 12 & 9.23 \\
$>60$ & 5 & 3.89 \\
Opearting & & \\
Bussiness (in year) & & \\
1-5 & 11 & 8.46 \\
6-10 & 35 & 26.92 \\
10-15 & 37 & 28.46 \\
16-20 & 20 & 22.30 \\
$>20$ & 18 & 13.46 \\
\hline
\end{tabular}

Table 1 shows a general overview of the age and business operations in the creative industries. Most creative industry players are 3449 years $(42.30 \%)$. It means that the creative industry players run the business on the productive age. Based on the length of business operations, most of them have a sufficient work experience since they run the business for 10-15 years $(28.46 \%)$.

Table 2. Description of Variables and Indicators

\begin{tabular}{lccc}
\hline \multicolumn{1}{c}{ Variable } & Mean & Median & SD \\
\hline Creativty & 3.63 & 3.50 & 0.56 \\
Maret Orientation & 3.89 & 3.94 & 0.66 \\
Inovation & 4.12 & 4.25 & 0.47 \\
Competitive & 3.96 & 4.00 & 0.53 \\
Advantage & 4.05 & 4.00 & 0.59 \\
Company & & & \\
Performance & & & \\
\hline
\end{tabular}

Table 2 shows an overview of the mean, medium and standard deviations of each variable. Market orientation variables in a high category which is indicated by its mean value (3.89). It shows that the industry creative in fashion sector run the business activity with consumer oriented. Business activity is always consumer oriented, which is done by creating good cooperation with the consumers, giving the best added value for consumer, trying to understand consumers' needs and trying to satisfy them.

Furthermore, to adapt with the business competition, creative industry should pay attention to all competitors' activities, share information about competitors and make decisions quickly to respond to the actions of competitors. Besides, they should conduct routine internal coordination o get team support in business decision making. Inter-functional coordination is required to create cohesiveness and cooperation and should be done through coordination between sections, share information and strategize together. The mean grade of creativity is 3.63 . It shows that the creative industry player's ability to get the original idea is still weak; to meet the unique and wide idea is not maximal. In addition, the variation of ideas that will be realized in the form of innovation is also limited.

The mean value of innovation variable is 4.12 , means that it belongs to the high category. This condition shows that the innovation has been done well and in accordance with consumer expectations. Innovation is realized in the form of introductions of new products in order to be able to provide a variety of alternative product choices that can satisfy consumers. Innovation for new product development that suits technological change demands. Moreover, company should be able to produce different products with competitors' to enter a new market.

The mean value of competitive advantages which is 3.96 belongs to the high category. This condition shows the ability to create competitive advantage made by the perpetrators of the creative industry is good. Competitive advantage is created by making efficiency in the production process to create a fair price that can compete in the market. Quality improvement is also done to satisfy consumers, as well as build good relationships with thm. Differentiation is also done in order to provide many choices for consumers. 
Sutapa, et al. / The Role of Market Orientation, Creativity and Innovation in...

Furthermore, the company's performance variable is included in the high category; with a mean value is 4.05 . This condition shows the performance of the creative industry has been relatively good, this can be indicated from the increase of return on assets every year, annual profit growth, annual sales growth and market share growth each year.

\section{Analysis Result}

The data obtained will be tested empirically based on Partial Least Square (PLS) with Smart PLS software. The analytical techniques will used to test the Hypothesis through the model of structural equations with Partial Least Square (PLS) approach. The approach through distribution free is a powerful research method in Partial Least Square (PLS), because it does not assume certain distributed data but it can be nominal, ordinal, interval and ratio and the number of samples should not be large (Ghozali, 2013).

\section{Outer Model (Validity and Reliability Test)}

The goal of the outer model test is to measure the specification of the relationship between latent variables and their indicators. Testing is done by Convergent Validity approa$\mathrm{ch}$, where indicator is judged by correlation between item score/ component score. Individual reflection sizes are said to be high if they correlate more than 0.70 with the measured constructs. Early stage studies of developing a scale of measuring the loading values of 0.50 to 0.60 are considered sufficient (Ghozali, 2013).

Table 3. Result of validity test

\begin{tabular}{llcc}
\hline Variable & Indicator & $\begin{array}{c}\text { Loadng } \\
\text { Factor }\end{array}$ & $\begin{array}{c}\text { Conclu- } \\
\text { sion }\end{array}$ \\
\hline Creativity & KRE1 & 0.952 & Valid \\
& KRE2 & 0.514 & Valid \\
& KRE3 & 0.659 & Valid \\
& KRE4 & 0.731 & Valid \\
\hline
\end{tabular}

\begin{tabular}{llll}
\hline Market & MO1 & 0.758 & Valid \\
Orientation & MO2 & 0.897 & Valid \\
& MO3 & 0.826 & Valid \\
& MO4 & 0.765 & Valid \\
& MO5 & 0.764 & Valid \\
& MO6 & 0.894 & Valid \\
& MO7 & 0.854 & Valid \\
& MO8 & 0.912 & Valid \\
& MO9 & 0.917 & Valid \\
\hline Innovation & PI1 & 0.710 & Valid \\
& PI2 & 0.815 & Valid \\
& PI3 & 0.716 & Valid \\
Competi- & CA1 & 0.676 & Valid \\
tive Advan- & CA2 & 0.690 & Valid \\
tage & CA3 & 0.764 & Valid \\
& CA4 & 0.621 & Valid \\
\hline Company & PF1 & 0.740 & Valid \\
perfor- & PF2 & 0.848 & Valid \\
mance & PF3 & 0.831 & Valid \\
& PF4 & 0.782 & Valid \\
\hline
\end{tabular}

The validity test result in Table 3 shows that the value of outer model indicates the factor loading value of each indicator is above 0.50 , so it can be concluded that all indicator is valid. Meanwhile, to measure reliability of variables is done by discriminant validity approach. It compares the square root values of Average Variance Extracted (AVE) in every construct by correlating between construct with others in the model. The model has good discriminant validity if the AVE root value of each latent variable is greater than the correlation value between latent variables with other latent variables in the model and recommended AVE values must be greater than 0.50 .

The reliability test result in Table 4 shows that the value of each Composite Reliability is above 0.60 and Average Variance Extracted (AVE) is 0.50. From the result, it can be concluded that this study has qualified reliability of a construct. 
Table 4. Reliability test results

\begin{tabular}{lcc}
\hline \multicolumn{1}{c}{ Variable } & $\begin{array}{c}\text { Composite } \\
\text { Reliability }\end{array}$ & AVE \\
\hline Creativty & 0.821 & 0.535 \\
Maret Orientation & 0.957 & 0.714 \\
Inovation & 0.815 & 0.536 \\
Competitive Advantage & 0.877 & 0.642 \\
Company Performance & 0.814 & 0.534 \\
\hline
\end{tabular}

\section{RESULT AND DISCUSSION}

Inner model is used to measure the relationship between structural model or inner relations. The great influence between research variables can be seen in Table 5 .

Inner model or structural model is performed to test the relationship between construct, significant value and R-square of the research model. The relationship between structural model explaining the relationship between latent variables in the study. Without losing the general nature, it is assumed that the latent variable and the indicator or variable manifest in the zero means and the variance unit are equal to one so that the constants parameters can be omitted from the model. In Table 5 above shows the influence between latent variables in the model and testing is done by comparing the value of $\mathrm{t}$ statistics with the value of $t$ in the table (1.96). If the statistical $t$ value is greater than $t$ value in the table, so there is a significant influence between latent variables and vice versa. The value of R-Square in Partial Least Square (PLS) model of each dependent latent variable can be seen in Table 6.

Table 6. R-square value

\begin{tabular}{lc}
\hline \multicolumn{1}{c}{ Variable } & R-square \\
\hline Inovation & 0.580 \\
Competitive Advantage & 0.757 \\
Company Performance & 0.784 \\
\hline
\end{tabular}

The analysis result in Table 6 shows the $\mathrm{R}$-square value of innovation variable is 0.580 . It shows that creativity variables influenced by creativity and market orientation variables are 0.580 or $58.0 \%$. The rest $(100 \%-58,00 \%=$ $42.0 \%)$ is explained by other variable outside research model. Furthermore, the R-square of competitive advantage variables is 0.757 means

Table 5. Relationship between Research Variables

\begin{tabular}{|c|c|c|c|c|c|}
\hline Relationship & $\begin{array}{l}\text { Original } \\
\text { Sample } \\
\text { Estimate }\end{array}$ & $\begin{array}{c}\text { Mean of } \\
\text { Subsamples }\end{array}$ & $\begin{array}{l}\text { Standard } \\
\text { Deviation }\end{array}$ & t-Statistic & Conclusion \\
\hline Creativity $\rightarrow$ Innovation & 0.072 & 0.070 & 0.092 & 0.777 & $\mathrm{H} 1$ is rejected \\
\hline Orientation $\rightarrow$ Innovation & 0.742 & 0.727 & 0.051 & 14.434 & $\mathrm{H} 2$ is accepted \\
\hline $\begin{array}{l}\text { Orientation } \rightarrow \text { Company } \\
\text { Performance }\end{array}$ & 0.184 & 0.187 & 0.087 & 2.110 & $\mathrm{H} 3$ is accepted \\
\hline $\begin{array}{l}\text { Innovation } \rightarrow \text { Competitive } \\
\text { Advantage }\end{array}$ & 0.870 & 0.871 & 0.018 & 48.585 & $\mathrm{H} 4$ is accepted \\
\hline $\begin{array}{l}\text { Innovation } \rightarrow \text { Company } \\
\text { Performance }\end{array}$ & 0.296 & 0.284 & 0.116 & 2.229 & H5 is accepted \\
\hline $\begin{array}{l}\text { Competitive } \\
\text { Advanatge } \rightarrow \text { Company } \\
\text { Performance }\end{array}$ & 0.463 & 0.472 & 0.080 & 5.790 & H6 is accepted \\
\hline
\end{tabular}


Sutapa, et al. / The Role of Market Orientation, Creativity and Innovation in...

that the competitive advantage variable is explained by the innovation variable of $75.7 \%$ and the rest $(100 \%-75.7 \%=24.3 \%)$ is explained by other variables outside the research model. While R-square of performance variable is 0.784 means that the performance of creative industry influenced by market orientation, innovation and competitive advantage is $78.4 \%$ and the rest $(100 \%-78.4 \%=22.6 \%)$ is explained by other variables outside the research model.

Creativity does not significantly affect innovation. This condition shows that the most of the ideas and the development concepts of creative industry players have not been realized in the form of product, process, market and management innovation. The results of this study support the previous study that creativity does not significantly affect innovation performance (Sohn \& Jung 2010). Similarly, research findings suggest that individual creativity is incapable of encouraging successful innovation (Steiner, 2009).

Creativity is really needed by creative industry players, because creativity can generate original and unique ideas. Ideas cannot be rea- lized in the form of innovation. Furthermore, ideas that vary as well as big ideas not yet fully implemented by creative industry players. The ability to get original and unique ideas is needed to support innovation. The ability to explore challenging and varied ideas is needed to support product, process, market and management innovations for creative industry players.

Market orientation significantly affects innovation, so the high activity of market-oriented company improves the innovation. The results of this study are in line with the findings of the previous study which states that the high the market orientation of the company improves the innovation of products, processes and markets and the high the level of competence improves of innovation (Martinez, 2013). The results of this study also support the findings stating that market orientation by small and medium enterprises can encourage innovation (Suliyanto \& Rahab, 2012; Remli et al., 2013). Market orientation is able to drive the success of innovation performance (Kaya \& Patton, 2011).

Market-oriented business decisions are embodied in three dimensions; consumer

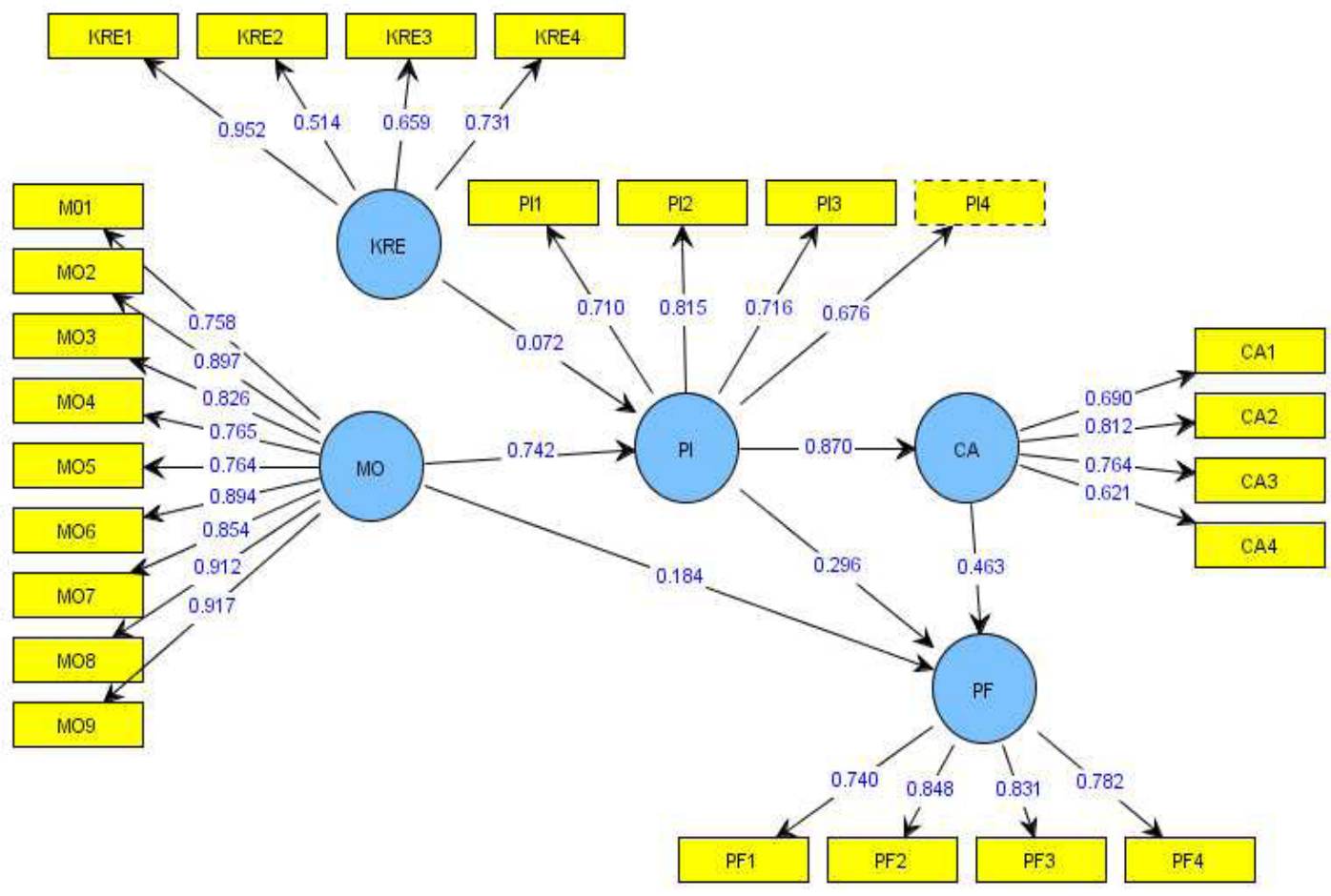

Figure 1. Conceptual Model 
orientation, competitor orientation and interfunctional coordination. The purpose of consumer orientation is to satisfy consumers through increased value added for consumers. Provide added value to larger consumers through a variety of product choices as a result of innovation. Besides, the creative industry should meet the consumers' needs by providing a wide selection of product variations and prices based on consumers' ability. Competitor orientation is done by sharing information and quickly in taking decisions to respond to competitors' actions and strategies. Internal coordination within the organization is always done to build a solid team that can be done by sharing information between sections, facilitating coordination and formulating strategies to develop shared innovations. In line with research that states market orientation can drive the success of innovation performance (Kaya \& Patton, 2011).

Market orientation significantly affects company performance, meaning that the stronger the market orientation will create the higher company performance. The results of this study support the findings of previous study which states that market orientation can improve business performance (Suliyanto \& Rahab, 2012; Oudan, 2012; Yadav, 2014). In line with the results of research, the market orientation through the dimensions of consumer orientation, competitor orientation, inter-functional coordination can be used to predict company performance (Yadav \& Tripathi, 2014).

Similarly, the business performance of small and medium businesses can be improved by consumer orientation and competitor orientation (Aziz \& Yassin, 2010). This result contradicts the opinion that market orientation has no significant effect on the performance of small and medium enterprises (Rosli \& Sidek, 2013; Gholami \& Birjandi, 2016). Another study shows that market orientation cannot improve the financial performance and growth of company owned by the family (Gerni, 2013).

Marketing policy conducted through three pillars; consumer orientation, competitor orientation and inter-functional coordination.
Consumer orientation is realized by creating better value added for consumers, by realizing greater consumer expectations compared to consumer sacrifices. Creative industry players should meet the needs of consumers by giving satisfaction to consumers better than competitors. In addition it also provides a wide selection of product variations and prices based on consumers' ability. Furthermore, competitor orientation is done by sharing information about competitors, quickly responding to competitor's actions and strategies. Inter-functional coordination is conducted in an integrated manner by coordinating among functions, sharing information between sections and building cooperation among members, building cooperation to formulate strategies in order to improve company performance.

Innovation significantly affects company performance. This condition shows that the better the innovation is, the higher the performance of the company. The results of this study are in line, with finding which states that the high the innovation creativity made by the company improved company performance (Sa$\lim \&$ Sulaiman, 2011). In line with the finding, the better the innovation capabilities of small and medium business actors can improve the company's performance (Sulistyo, 2016). It also supports the statement that company performance can be improved through the innovation quality (Lakhal, 2009; Salim \& Sulaiman, 2011; Mahmood, 2013). The development of innovations in introducing new products to consumers and creating products by using new technology will add value to consumers. Differentiation of products is done to provide many choices for consumers and entering the market with new products encourage sales, profits and also return on asset creative industry players.

Innovation significantly affects competitive advantage, so the higher the innovation capability is, the higher the competitive advantage. This result supports previous research which states that the ability to innovate affects the competitive advantage (Parkman, 2012; Wingwon, 2012). Competitive advantage can 
Sutapa, et al. / The Role of Market Orientation, Creativity and Innovation in...

be created through superior value, quality, innovation and effectiveness (Chiou, 2011), as well as competitive advantage can be achieved through innovation motivation (Dustin et al., 2014). Innovation affects individual and organizations performance which impact on competitive advantage. Innovation through new product designs as well as product development by using new technologies encourage efficient production that impact on cheap pricing. Differentiation of products and market entry with new products faster than competitors will be able to create competitive advantage.

Competitive advantage significantly affects company performance. The higher the ability to create competitive advantage is, the higher creative industry performance. The result of this study reinforces the finding that competitive advantage can improve business performance (Russell \& Millar, 2014; Mulyana, 2016). Correspondingly, this research findings competitive advantage can improve organizational performance (Lakhal, 2009; Russell \& Millar, 2014). Holistic competitive advantage can improve company performance (Ren, 2010). This condition shows that competitive advantage is the key to long-term business performance for creative industries. Competitive advantage is built through the creation of quality products and lower prices than other companies in the same industry. Competitive advantage can be created by building good relationships with customers that can drive increased sales, profit and market share.

\section{CONCLUSION AND RECOMMENDATION}

The policy of market-oriented innovation development encourages the creation of sustainable competitive advantage for the creative industry. The performance of the creative industry can be improved if the policy of market-oriented innovation is developed by focusing on consumer orientation, competitor orientation and inter-functional coordination. Similarly, performance can be improved if the creative industry has a competitive advantage.
The managerial implication of this research is that innovation development to create competitive advantage can be done by developing consumer oriented marketing policy, competitor orientation and good inter-functional coordination. Improving the performance of categorical industry can be done by conducting business policy focusing on market orientation, continuous innovation and creating competitive advantage.

The limitation of this research is the result of model development with the level of marginal accuracy and the respondent has different background of both creative and educational industry sector, so the answer to the questionnaire given becomes heterogenic. Future research is expected to test the type of creative industry, by adding business environment variables as well as firm size as moderating variables.

\section{REFERENCES}

Afsharghasemi, A., Zain, M., Sambasivan, M \& Imm, S. N. S. 2013. Market Orientation, Government Regulation, Competitive Advantage and Internationalization of SMEs: a Study in Malaysia. Journal of Business Administration Research. 2 (2): 13-23.

Altuntaş, G., Semerciöz, F \& Eregez, H. 2013. Linking Strategic and Market Orientations to Organizational Performance: the Role of Innovation in Private Healthcare Organizations. Procedia-Social and Behavioral Sciences. 99: 413-419.

Ar, I. M. 2012. The Impact of Green Product Innovation on Firm Performance and Competitive Capability: the Moderating Role of Managerial Environmental Concern. Procedia-Social and Behavioral Sciences. 62: 854-64.

Armanio, J. M., Ruiz, D. M \& Armanio, E. M. 2008. Market Orientation and Internationalization in Small and Medium-Sized Enterprises. Journal of small Business Management. 46 (4): 485-511.

Asikhia, O. 2010. Customer Orientation and Firm Performance among Nigerian Small and Medium Scale Businesses. International Journal of Marketing Studies. 2 (1): 197-212. 
Augusto, M \& Coelho, F. 2009. Market Orientation and New-to-the-World Products: Exploring the Moderating Effects of Innovativeness, Competitive Strength and Environmental Forces. Industrial Marketing Management. 38 (1): 94-108.

Awuah, G. B. 2008. Networked (Interactive) Position: a New View of Developing and Sustaining Competitive Advantage. Competitiveness Review: an International Business Journal. 18 (4): 333-50.

Awwad, M. S., Ali, D \& Agti, M. 2011. The Impact of Internal Marketing on Commercial Banks' Market Orientation. International Journal of Bank Marketing. 29 (4): 308-32.

Azadehdel, M. R., Farahbod, F \& Jamshidinejad, M. A. 2013. The Relationship between Knowledge Sharing, Innovation and Performance of Manufacturing and Trading Companies in Guilan Province. Inter Diciplinary Journal of contemporary research in Business. 5 (5): 40813.

Aziz, N. A \& Yassin, N. M. 2010. How Will Market Orientation and External Environment Influence the Performance among SMEs in the Agro-Food Sector in Malaysia?. International Business Research. 3 (3): 154-164.

Charterina, J \& Landeta, J. 2013. Effects of Knowledge-Sharing Routines and Dyad-Based Investments on Company Innovation and Performance: an Empirical Study of Spanish Manufacturing Companies. International journal of Management. 30 (1): 20-40.

Chen, Y \& Chang, C. 2013. The Determinants of Green Product Development Performance: Green Dynamic Capabilities, Green Transformational Leadership and Green Creativity. Journal of Business Ethics 116: 107-19.

Chiou, C. 2011. Dynamic Capabilities, Collaborative Network and Business Model: an Empirical Analysis of Taiwan HTC Corporation. African Journal of Business Management. 5 (2): 294-305.

Dirisu, J. I., Iyiola, O \& Ibidunni, O. S. 2013. Product Differentiation: a Tool of Competitive Advantage and Optimal Organizational Performance. European Scientific Journa. 9 (34): 258-281.

Dustin, G., Bharat, M \& Jitendra, M. 2014a. Competitive Advantage and Motivating Innovation. Advant in Management. 7 (1): 1-8.
Farida, N. 2016. Determinants of Marketing Performance: Innovation, Market Capabilities and Marketing Performance. Jurnal Dinamika Manjemen. 7 (1): 59-65.

Fong, C \& Chang, N. 2012. The Impact of Green Learning Orientation on Proactive Environmental Innovation Capability and Firm Performance. African Journal of Business Management. 6 (3): 727-135.

Gerni, G. M. 2013. Evaluating the Effects of Market and Innovation Orientations on Family Owned Firms' Performance: an Empirical Study in Istanbul. Advances in Management \& Applied Economics. 3 (5): 139-150.

Gholami, S \& Birjandi, M. 2016. The Effect of Market Orientation and Entrepreneurial Orientation on the Performance of SMEs. Journal of Current Research in Science. 5 (1):361-69.

Halim, M. A. S. A., Muda, S \& Amin, W. A. A. W. M. 2011. The Measurement of Entrepreneurial Personality and Business Performance in Terengganu Creative Industry. International Journal of Business and Management. 6 (6): 183-93.

Hassan, M. U., Qureshi, S. U., Hasnain, A., Sharif, I \& Hassan, R. 2013. Market Orientaion, Learning Orientation and Organizational Performance: Evidence from Banking Industry of Pakistan. Science International. 25 (4): 945-956.

Hosseini, M. 2012. An Investigation on the Effect of Supply Chain Integration on Competitive Capability: an Empirical Analysis of Iranian Food Industry. International Journal of Business and management. 7 (5): 73-91.

Hsu, S. 2012. Effects of Competitive Strategy, Knowledge Management and E-Business Adoption on Performance. The Journal of Human Resource and Adult Learning. 8 (2): 4250.

Ghozali, I. 2013. Apikasi Analisis Multivariat dengan Program SPSS 21. Semarang: Badan Penerbit Universitas Diponegoro.

Jardon, C. M \& Martos, M. S. 2013. Intellectual Capital as Competitive Advantage in Emerging Clusters in Latin America. Journal of Intellectual Capital. 13 (4): 462-81.

Kamukama, N., Ahiauzu, A \& Ntayi, J. M. 2011. Competitive Advantage: Mediator of Intellectual Capital and Performance. Journal of Intellectual Capital. 12 (1): 152-64. 
Sutapa, et al. / The Role of Market Orientation, Creativity and Innovation in...

Karacaoglu, K., Bayrakdaro, A \& San, F. B. 2013. The Impact of Corporate Entrepreneurship on Firms' Financial Performance: Evidence from Istanbul Stock Exchange Firms. International Business Research. 6 (1): 163-176.

Kaya, N \& Patton, J. 2011. The Effects of Knowledge-Based Resources, Market Orientation and Learning Orientation on Innovation Performance: an Empirical Study of Turkish Firms. International Bibliography of the Social Sciences. 23 (2): 204-219.

Kok, R. A. W \& Biemans, W. G. 2009. Technovation Creating a Market-Oriented Product Innovation Process: a Contingency Approach. Technovation. 29 (8): 517-26.

Lakhal, L. 2009. Impact of Quality on Competitive Advantage and Organizational Performance. Journal of the Operational Research Society. 60 (5): 637-345.

Liu, H., Ke, W., Wei, K. K \& Hua, Z. 2011. Effects of Supply Chain Integration and Market Orientation on Firm Performance Evidence from China. International Journal of Operation and Production Management. 33 (3): 322-346.

Maatoofi, A. R \& Tajeddini, K. 2011. Effect of Market Orientation and Entrepreneurial Orientation on Innovation Evidence from Auto Parts Manufacturing in Iran. Journal of Management Research. 11 (1): 20-30.

Mahmood, R. 2013. Entrepreneurial Orientation and Business Performance of WomenOwned Small and Medium Enterprises in Malaysia: Competitive Advantage as a Mediator. International Journal of Business and Social Science. 4 (1): 82-91.

Martinez, C., Guzman, G. M \& Martinez, C. 2013. The Relationship between Market Orientation and Innovation in Mexican Manufacturing SME'S. Advances in Management and Applied Economics. 3 (5): 125-37.

Mehrabani, S. E. 2012. Knowledge Management and Innovation Capacity. Journal of Management Research. 4 (2): 164 - 177.

Mirza, W. A. 2011. The Dilemma of Knowledge Management, Innovation and Entrepreneurship in SME'S: an Empirical Study. Interdiciplinary Journal of Contaporary Research in Business. 3 (20): 1112-1129.

Mulyana, S . 2016. The Impact of Entrepreneurial Orientation and Collaborative Networks on
Creative Industries Performance. Journal Dinamika Manajemen. 7 (2): 166-81.

Najib, M., Dewi, F. R \& Widyastuti, H. 2014. Collaborative Networks as a Source of Innovation and Sustainable Competitiveness for Small and Medium Food Processing Enterprises in Indonesia. International Journal of Business and Management. 9 (9): 147-60.

Oudan, R. 2012. Market Orientation-Transforming Trade and Firm Performance. International Journal of Marketing Studies. 4 (2): 3-9.

Pantouvakis, A., Vlachos, I \& Zervopoulos, P. D. 2017. Market Orientation for Sustainable Performance and the Inverted-U Moderation of Firm Size: Evidence from the Greek Shipping Industry. Journal of Cleaner Production. 165: 705-720.

Parkman, I. D., Holloway, S. S \& Sebastiao, H. 2012. Creative Industries: Aligning Entrepreneurial Orientation and Innovation Capacity. Journal of Research in Marketing and Entrepreneurship. 14 (1): 95-114.

Permatasari, A \& Dhewanto, W. 2013. Business Model Innovation towards Competitive Advantage: Case Study in Indonesian Cosmetics and Herbal Health Companies. Information Management and Business Review. 5 (8): 385-393.

Peter S. D., Babakus, E., Englis-Danskin, P \& Pett, T. 2010. The Influence of CEO Gender on Market Orientation and Performance in Service Small and Medium-sized Service Businesses. Journal of Small Business Management. 48 (4): 475-496.

Putri, V. W \& Yuniawan, A. 2016. Organizational Effectiveness: Social Capital and Competitive Advantage Approach. Jurnal Dinamika Manajemen. 7 (1): 76-90.

Remli, N., Daud, W. N. W., Zainol, F. A \& Muhammad, H. 2013. A Proposed Conceptual Framework for Market Orientation and Innovation towards Takaful Performance in Malaysia. International Journal of Business and Management. 8 (7): 100-106.

Ren, L., Xie, G \& Krabbendam, K. 2010. Sustainable Competitive Advantage and Marketing Innovation within Firms. Management Research Review. 31 (1): 79-89.

Rosli, M. M \& Sidek, S. 2013. The Impact of Innovation on the Performance of Small and Medium Manufacturing Enterprises: Evidence 
from Malaysia. Journal of Innovation Management in Small \& Medium Enterprise. 1-16.

Russell, S. N \& Millar, H. H. 2014. Exploring the Relationships among Sustainable Manufacturing Practices, Business Performance and Competitive Advantage: Perspectives from a Developing Economy. Journal of Management and Sustainability. 4 (3): 37-54.

Salim, I. M \& Sulaiman, M. 2011. Organizational Learning, Innovation and Performance: a Study of Malaysian Small and Medium Sized Enterprises. International Journal of Business and Management. 6 (12): 118-26.

Sanchez-Gutierrez, J., Gonzalez-Uribe, E. G., Gutierrez-govea, A \& Garcia-jimenez, E. F. 2012. Competitiveness: an Analysis of the Restaurant Industry. Advances in Competitiveness Research. 20 (3): 32-46.

Santos-vijande, L. 2012. Marketing Capabilities Development in Small and Medium Enterprises: Implications for Performance Marketing Capabilities Development in Small and Medium. Journal of Centrum Cathedra. 5 (1): 2012.

Shoemaker, M. E \& Pelham, A. M. 2013. Does Salesperson Perception of the Firm-Level of Market Orientation Influence Sales Behavior and Performance Attributions?. Journal of Managerial Issues. 25 (4): 381-400.

Singh, H \& Mahmood, R. 2013. Determining the Effect of Export Market Orientation on Export Performance of Small and Medium Enterprises in Malaysia: an Exploratory Study. Advances in Management \& Applied Economics. 3 (6): 223-32.

Sohn, S. Y \& Jung, C. S. 2010. Effect of Creativity on Innovation: Do Creativity Initiatives Have Significant Impact on Innovative Performance in Korean Firms?. Creativity Research Journal. 22 (3): 320-28.

Sousa, F. C. D. 2012. Creativity, Innovation and Collaborations. International Journal of Organizational Innovation. 5 (1): 26-65.

Steiner, G. 2009. The Concept of Open Creativity: Collaborative Creative Problem Solving for Innovation Generation-a System Approach.
Journal of Business \& Management. 15 (1): 5-33.

Sugianto, L \& Hartono, S. 2017. Enhancing Capability of Human Resources Innovation. Jurnal Dinamika Manajemen. 8 (1): 108-121.

Sulistyo, H. 2016. Asia Pacific Management Review Innovation Capability of SMEs through Entrepreneurship, Marketing Capability, Relational Capital and Empowerment. Asia Pacific Management Review. 21 (4): 196-203.

Suliyanto \& Rahab. 2012. The Role of Market Orientation and Learning Orientation in Improving Innovativeness and Performance of Small and Medium Enterprises. Asian Social Science. 8 (1): 134-145.

Upadhyay, A \& Sivakumar, N. 2015. Impact of Marketing Orientation on Financial Performance of Banks in India. International Journal of Banking, Risk and Insurance Rrelationship. 3 (1): 36-45.

Vytlacil, L. L. 2010. Market Orientation and Business Performance: the Role of Positional Advantage. Disertation. Minneapolis: Capella University.

Widana, G. O., Wirjono, S. K., Purwanegara, M. S \& Toha, M. 2015. The Role of Business Ethics in the Relationship between Market Orientation and Business Performance. International Journal of Finance \& Banking Studies. 4 (1): 95-112.

Wingwon, B. 2012. Effects of Entrepreneurship, Organization Capability, Strategic Decision Making and Innovation toward the Competitive Advantage of SMEs Enterprises. Journal of Management and Sustainability. 2 (1): 137-51.

Wong, H \& Ellis, P. D. 2007. Is Market Orientation Affected by the Product Life Cycle? Journal of Word Business. 42: 145-56.

Yadav, S. K \& Tripathi, V. 2014. Market Orientation and SMEs Performance. Journal of Entrepreneurship and Management. 3 (3): 27-34.

Yuan Li., Zhao, Y., Tan, J \& Liy, Y. 2008. Moderating Effects of Entrepreneurial Orientation on Market. Journal of Small Business Management. 46 (1): 113-33. 